\title{
Bovine preimplantation embryos with silenced nucleophosmin mRNA are able to develop until the blastocyst stage
}

\author{
Tereza Toralová ${ }^{1}$, Veronika Benešová1,2, Kateřina Vodičková Kepková ${ }^{1}$, Petr Vodička ${ }^{1}$, \\ Andrej Šušor ${ }^{3}$ and Jiří Kaňka ${ }^{1}$ \\ ${ }^{1}$ Laboratory of Developmental Biology, Institute of Animal Physiology and Genetics Academy of Sciences of the \\ Czech Republic, v.v.i., Rumburská 89, 27721 Liběchov, Czech Republic, ${ }^{2}$ Faculty of Science, Charles University in \\ Prague, Albertov 6, 12843 Prague, Czech Republic and ${ }^{3}$ Department of Obstetrics, Gynecology and Reproductive \\ Sciences, Center for Reproductive Sciences, University of California, San Francisco, California 94143-0556, USA \\ Correspondence should be addressed to T Toralová; Email: moravcova@iapg.cas.cz
}

\begin{abstract}
This study was conducted to investigate the effect of silencing nucleophosmin in the development of in vitro-produced bovine embryos. Nucleophosmin is an abundant multifunctional nucleolar phosphoprotein that participates, for example, in ribosome biogenesis or centrosome duplication control. We showed that although the transcription of embryonic nucleophosmin started already at late eightcell stage, maternal protein was stored throughout the whole preimplantation development and was sufficient for the progression to the blastocyst stage. At the beginning of embryogenesis, translation occurs on maternally derived ribosomes, the functionally active nucleoli emerge during the fourth cell cycle in bovines. We found that nucleophosmin localisation reflected the nucleolar formation during bovine preimplantation development. The protein was detectable from the beginning of embryonic development. Before embryonic genome activation, it was dispersed throughout the nucleoplasm. The typical nucleolar localisation emerged with the formation of active nucleoli. At the blastocyst stage, nucleophosmin tended to localise especially to the trophectoderm. To see for how long is maternal nucleophosmin preserved, we silenced the nucleophosmin mRNA using RNA interference approach. Although a large portion of nucleophosmin was degraded in embryos with silenced nucleophosmin mRNA, an amount sufficient for normal development was preserved and we detected only a temporal delay in nucleophosmin relocalisation to nucleoli. Moreover, we observed no defects in nuclear shape or cytoskeleton previously found in somatic cells and only a non-significant decrease in embryonic developmental competence. Thus, our results show that the preserved amount of maternal nucleophosmin is sufficient for preimplantation development of bovine embryo.

Reproduction (2012) 144 349-359
\end{abstract}

\section{Introduction}

The preimplantation development of mammals still hides many secrets, especially regarding gene expression. After fertilisation, the embryonic genome is gradually activated, starting with minor genome activation, presumably initiated at two- to four-cell stages in bovines and followed by major genome activation at late eight-cell stage (Memili \& First 1998, Kanka 2003). Although the role of many transcripts during early embryogenesis was revealed (Nganvongpanit et al. 2006a, 2006b, Toralova et al. 2009, Salilew-Wondim et al. 2010) and many potentially important genes were identified (Hamatani et al. 2004, Kanka et al. 2009, Vodickova Kepkova et al. 2011), the role of plenty of others is still far from clear.

Nucleophosmin (NPM1, B23, numatrin and NO38) is an abundant multifunctional phosphoprotein, whose most important roles are rRNA processing, ribosome biogenesis and centrosome duplication control (Borer et al. 1989, Savkur \& Olson 1998, Hingorani et al. 2000, Okuwaki et al. 2002). Moreover, nucleophosmin acts as a histone chaperone and is thus involved in controlling chromatin transcription (Swaminathan et al. 2005). Much like many other proteins engaged in ribosome biogenesis, nucleophosmin shuttles between nucleolus and cytoplasm or non-nucleoli region of the nucleus (Borer et al. 1989, Yung et al. 1990, Valdez et al. 1994, Chen \& Huang 2001) and participates in protein transport, for example, of p120 (Valdez et al. 1994), Rex protein (Adachi et al. 1993), Rev protein (Fankhauser et al. 1991) or nucleolin (Li et al. 1996).

At the beginning of mammalian embryogenesis, all the mRNAs and plenty of the proteins used by the embryo come from reserves that were generated during oocyte maturation. Nucleophosmin seems to originate from maternal reserves at least until the eight-cell stage, when 
it starts to transfer to the developing nucleolus in bovine preimplantation embryo (Svarcova et al. 2007).

During the first three cycles, electron-dense spherical masses of tightly packed fibrils, called nucleolar precursor bodies (NPBs), are present in the embryonic nucleus. rRNA synthesis is inactive during this period. Transformation of the NPBs into fibrogranular nucleoli at the time of major genome activation represents the formation of typical rRNA synthesising nucleolus (Camous et al. 1986, King et al. 1988, Kopecny et al. 1989, Pavlok et al. 1993). It has been proposed that nucleophosmin together with nucleolin functions in the assembly of pre-ribosomal particles (Biggiogera et al. 1990). Nucleophosmin inheres in the peripheral portion of the dense fibrillar component and the granular component of nucleolus (Spector et al. 1984) that emerges at the end of fourth cell cycle in cattle (Camous et al. 1986, King et al. 1988, Kopecny et al. 1989, Laurincik et al. 2000). Although it seems that maternal nucleophosmin is stored even after the embryonic genome activation (EGA), it is not able to transfer to the evolving nucleoli in $\alpha$-amanitin-treated embryos and remains dispersed in the nucleoplasm (Bjerregaard et al. 2004, Svarcova et al. 2007).

Silencing of nucleophosmin in somatic cells causes disorganisation of nuclear and nucleolar structures with the formation of micronuclei, delays mitosis, suspends DNA synthesis and induces activation of p53 (Amin et al. 2008a, 2008b). Moreover, many of the NPM1 ${ }^{-1-}$ cells hold multiple centrosomes or are multinucleated (Grisendi et al. 2005). The role of nucleophosmin in cell proliferation is still far from clear. Nucleophosmin is generally overexpressed in proliferating cells, but on the other hand, it is important for the maintenance of genome stability and acts as proliferative suppressor (Grisendi et al. 2005). The Npm1 $1^{-1-}$ mouse embryos were implanted into the endometrium without any detectable defect, nevertheless they die during the ongoing development (Colombo et al. 2005, Grisendi et al. 2005). Here, we show that even though the amount of maternal protein continuously decreases in bovine preimplantation embryos, the remaining protein is sufficient for normal preimplantation development of embryos with silenced nucleophosmin mRNA.

\section{Results}

\section{The expression of nucleophosmin mRNA from embryonic genome starts at late eight-cell stage}

Quantitative RT-PCR analysis of the expression pattern of nucleophosmin transcript during in vitro culture (from MII oocyte to blastocyst stage; Fig. 1A) showed a significant decrease in transcript level from MII oocyte to two-cell stage. From two-cell stage to early eight-cell stage, the mRNA level slightly decreased and thereafter increased at late eight-cell stage; however, neither of
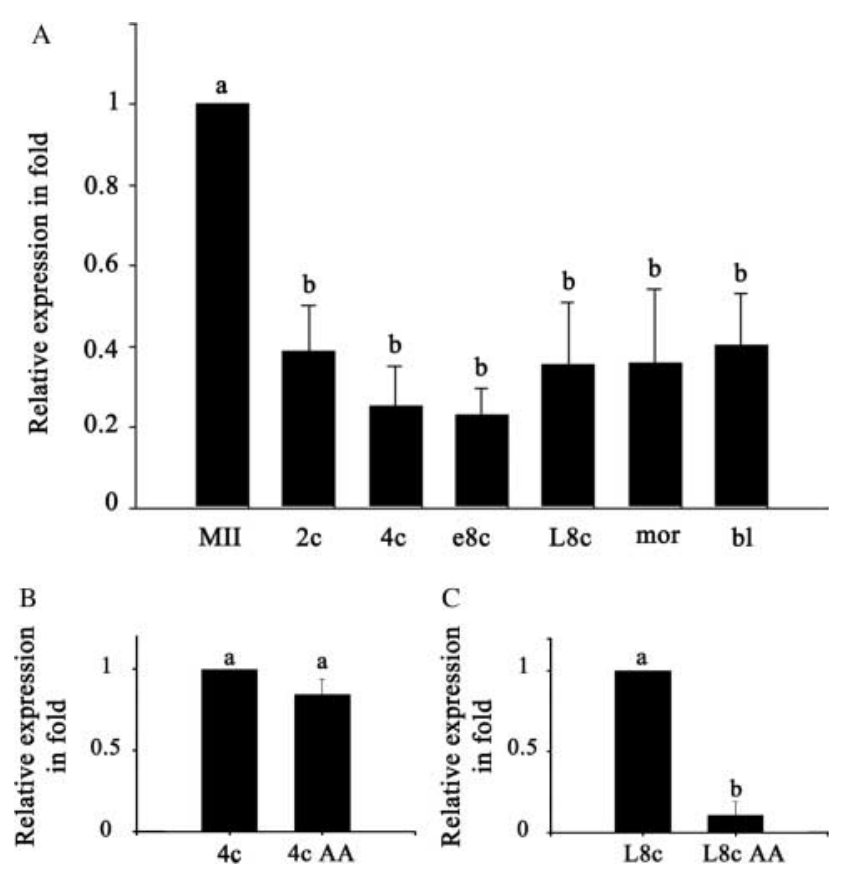

Figure 1 Relative abundance of nucleophosmin mRNA during bovine preimplantation development. The data were normalised according to the relative concentration of the external standard (luciferase mRNA, 1 pg per oocyte/embryo). (A) Untreated embryos; (B) embryos treated with $\alpha$-amanitin from one-cell stage to four-cell stage and (C) embryos treated with $\alpha$-amanitin from four-cell stage to eight-cell stage.

Bars show mean \pm s.D. ${ }^{a, b}$ Values with different superscripts indicate statistical significance $(P<0.05)$. (MII, MIl stage oocyte; $2 \mathrm{C}$, two-cell embryo; 4c, four-cell embryo; e8c, early eight-cell embryo; L8c, late eight-cell embryo; mor, morula; bl, blastocyst; 4c AA, four-cell embryo cultivated with $\alpha$-amanitin; L8c AA, late eight-cell embryo cultivated with $\alpha$-amanitin).

these changes was statistically significant. After EGA, the mRNA level remained approximately the same until the blastocyst stage. To see at which stage the transcription of nucleophosmin from embryonic genome is started, embryos were cultured from one-cell stage to four-cell stage and from four-cell to eight-cell stage in the presence of RNA polymerase II inhibitor $\boldsymbol{\alpha}$-amanitin at a final concentration of $100 \mu \mathrm{g} / \mathrm{ml}$. While we detected no significant difference in nucleophosmin transcript abundance in $\alpha$-amanitin-treated four-cell embryos in comparison with controls (Fig. 1B), a significant decrease in nucleophosmin mRNA level was found in $\alpha$-amanitintreated late eight-cell stage embryos (Fig. 1C).

\section{The dynamics of nucleophosmin localisation and expression during bovine preimplantation development}

As there were some contradictory studies concerning nucleophosmin localisation during early embryo development of cattle (Laurincik et al. 2000, Fair et al. 2001), we performed the immunofluorescence analysis of in vitro cultured embryos from two-cell stage to blastocyst stage (Fig. 2). In embryos before EGA (pre-EGA embryos; two-cell and four-cell embryos), 
pre-EGA (2c)
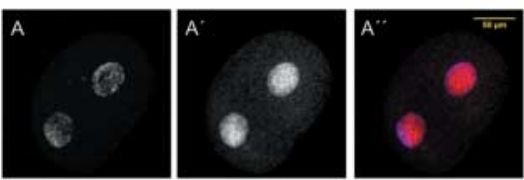

pre-EGA mitosis
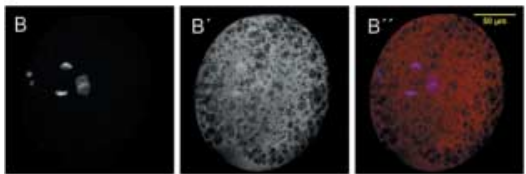

early $8 \mathrm{c}$
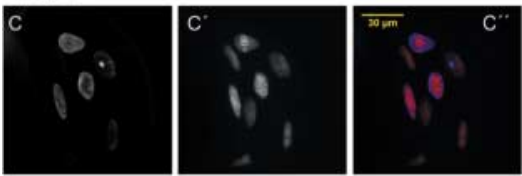

early $8 \mathrm{c}$ - nucleus detail
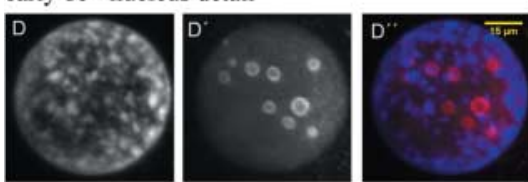

late $8 \mathrm{c}$

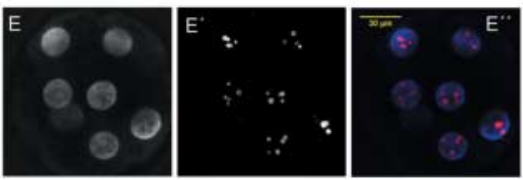

post-EGA (morula)
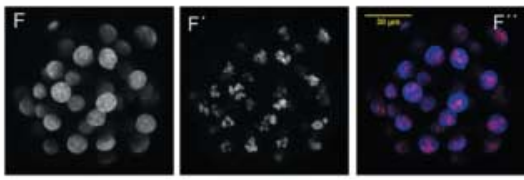

post-EGA mitosis
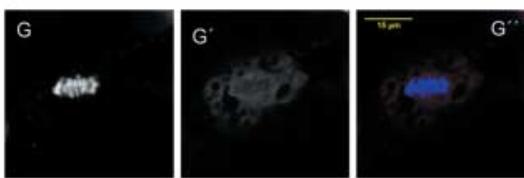

blastocyst
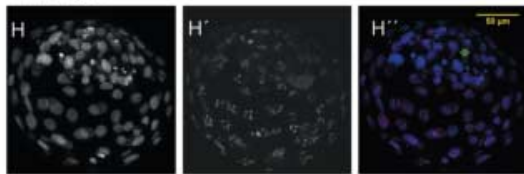

hatched blastocyst

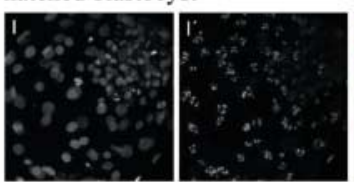

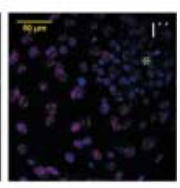

Figure 2 Confocal laser scanning microscopy of preimplantation embryos from two-cell stage to hatched blastocyst. In D, $\mathrm{D}^{\prime}$, and $\mathrm{D}^{\prime \prime}$ and $\mathrm{G}, \mathrm{G}^{\prime}$, and $G^{\prime \prime}$, single nucleus of early eight-cell and morula stage embryo is shown respectively. The embryos were labelled with mouse monoclonal anti-nucleophosmin antibody $\left(\mathrm{A}^{\prime}-\mathrm{I}^{\prime}\right)$ and the nuclei were stained with DAPI (A, B, C, D, E, F, G, $H$, and $I)$. In mergers $\left(A^{\prime \prime}-I^{\prime \prime}\right)$, nucleophosmin is red and DNA blue. Asterisks in $\mathrm{H}^{\prime \prime}$ and $\mathrm{I}^{\prime \prime}$ indicate inner cell mass.

nucleophosmin was very abundant and was distributed mainly in the nucleoplasm. During mitosis, the protein dispersed throughout the whole blastomere with a very slight colocalisation with chromatin. With the formation of nucleolus, nucleophosmin formed shell-like structures (early eight-cell stage) and consequently, as the nucleolus became functionally active, the localisation pattern shifted to be typical for somatic cell nucleoli (late eight-cell stage and beyond, i.e. after EGA). We did not detect colocalisation of nucleophosmin and chromatin in post-EGA embryos, and the staining in mitotic blastomeres was generally much weaker. In late blastocysts (starting with day 7), nucleophosmin localised predominantly to the trophectoderm (TE). The difference became most apparent in hatched blastocysts.

Further, we analysed the expression rate in MII oocytes, four-cell embryos and morulas using western blot (Fig. 3B). The amount of nucleophosmin increased slightly from MII oocyte to four-cell stage and further more significant increase was detected at morula stage.

\section{Nucleophosmin mRNA and protein silencing}

To reveal whether nucleophosmin mRNA expression is required for early embryo development, we silenced nucleophosmin mRNA by microinjection of nucleophosmin dsRNA into bovine zygotes. The microinjection of nucleophosmin dsRNA efficiently (Fig. 4) and specifically (Fig. 5) caused degradation of nucleophosmin mRNA in bovine preimplantation embryos.

The nucleophosmin mRNA was reduced by $86.8 \%$ $(P<0.001)$ in comparison with uninjected control and by $83.6 \%(P<0.001)$ in comparison with GFP dsRNAinjected control. No significant difference was found in the abundance of nucleophosmin mRNA between the uninjected group and GFP dsRNA-injected group $(P>0.05)$. The experiment was repeated four times.

To verify the specificity of nucleophosmin mRNA degradation, we measured the level of mRNA of two control genes: centromeric protein $\mathrm{F}$ (CENPF) and C-type lectin domain family 2, member D (CLEC2D). We did not find any significant difference in mRNA levels between individual groups ( $P>0.05$ in each case). The experiment was repeated four times.

Further, we performed the immunoblotting analysis of four-cell stage embryos and morulas to monitor protein silencing. A considerable decrease in protein abundance in nucleophosmin dsRNA-injected embryos compared with uninjected control especially at morula stage was found; however, a small protein amount was still detectable (Fig. 6).

When we analysed localisation of the residual nucleophosmin, we found no protein localisation changes in embryos injected with nucleophosmin 

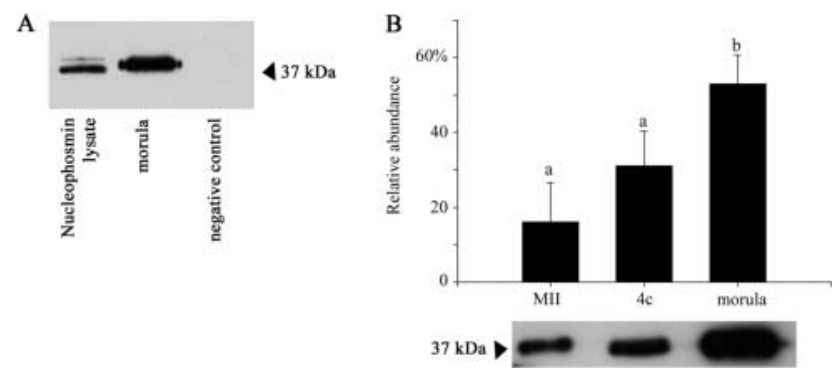

Figure 3 (A) The test of anti-nucleophosmin antibody specificity using western blot analysis. Nucleophosmin lysate was used as positive control and empty vector was used as negative control. Twenty-six embryos at the morula stage were analysed the same time.

(B) Quantification of nucleophosmin protein level after western blot analysis of bovine oocytes and preimplantation embryos (45 embryos per lane). The data were processed using Quantity One software (Bio-Rad). 100\% represents the sum of trace quantity of all bands; relative abundance ( $y$-axis) represents the percentage of each band. Bars show mean \pm s.D. ${ }^{a, b}$ Values with different superscripts indicate statistical significance $(P<0.05)$. The experiment was repeated three times, and the representative western blot picture is shown below the graph. (MII, MII oocytes; 4c, four-cell stage embryos).

dsRNA when compared with both control groups, whether in embryos arrested in early stages or normally developing embryos (Fig. 7). We only detected a slight delay in nucleophosmin relocalisation from nucleoplasm to nucleoli. In eight-cell stage, only five of 60 blastomeres $(8.3 \%)$ in uninjected group and three of 53 blastomeres (5.6\%) in GFP dsRNA-injected group still displayed entirely nucleoplasmic localisation, while the same was true for 18 of 73 blastomeres $(24.6 \%)$ in nucleophosmin dsRNA-injected embryos. Nevertheless, the localisation was purely nucleolar already at the 16 -cell stage in all three experimental groups.

\section{Developmental competence of nucleophosmin dsRNA-injected embryos is not significantly diminished}

To investigate the effect of nucleophosmin mRNA silencing on preimplantation development, we monitored the capacity of embryos in all three experimental groups to develop from two-cell stage to blastocyst stage. We found a decrease in the number of embryos injected with nucleophosmin dsRNA that reached the blastocyst stage. This deterioration was clearly noticeable in comparison to both control groups (mean \pm s.D.: uninjected control, $31.67 \% \pm 8.27$; GFP dsRNA-injected control, $26.76 \% \pm 11.50$; nucleophosmin dsRNA injected, $13.96 \% \pm 7.28)$, but the difference was not statistically significant (A significant, however boundary, $P$ value $(P=0.05)$ was found when comparing nucleophosmin dsRNA-injected group and uninjected group.) (Fig. 8). The experiment was repeated four times.

Of several defects found in $N P M 1^{-1-}$ cells and embryos (Colombo et al. 2005, Grisendi et al. 2005, Amin et al. 2008a, 2008b), we focused on the defect in tubulin polymerisation. We wanted to know whether the decrease in protein abundance proven by western blot causes some developmental defects or whether the residual protein is sufficient. We did not detect any nucleus shape defect or cytoskeleton deformation (Fig. 9).

\section{Discussion}

The function of nucleophosmin in somatic cells and the presently available results concerning its expression in early embryos suggest its potential importance during preimplantation development (Bjerregaard et al. 2004, Svarcova et al. 2007, Amin et al. 2008a, 2008b). To provide an experimental basis for this assumption, we determined the level of nucleophosmin mRNA expression in individual developmental stages of early embryogenesis with special emphasis on the EGA stage. The expression profile of genes in individual stages reflects their importance during preimplantation development, genes activated immediately at EGA being assumed to be the most important. As we found that the embryonic transcription starts from nucleophosmin gene at late eight-cell stage, the transcription of nucleophosmin from embryonic genome seems to be necessary and hence we proceeded to further analysis.

We wanted to determine the expression and localisation pattern of nucleophosmin protein during whole preimplantation development. During early embryogenesis, nucleophosmin localisation clearly reflected the formation of the nucleolus. In pre-EGA embryos, where no functional nucleolus is present, the protein was dispersed throughout the nucleoplasm, and during mitosis, it diffused all over the blastomere (Fig. 2A, $A^{\prime}, A^{\prime \prime}, B, B^{\prime}$, and $\left.B^{\prime \prime}\right)$. In pre-EGA embryos, we were able to detect nucleophosmin staining earlier Laurincik et al. (2000) and Svarcova et al. (2007), who show

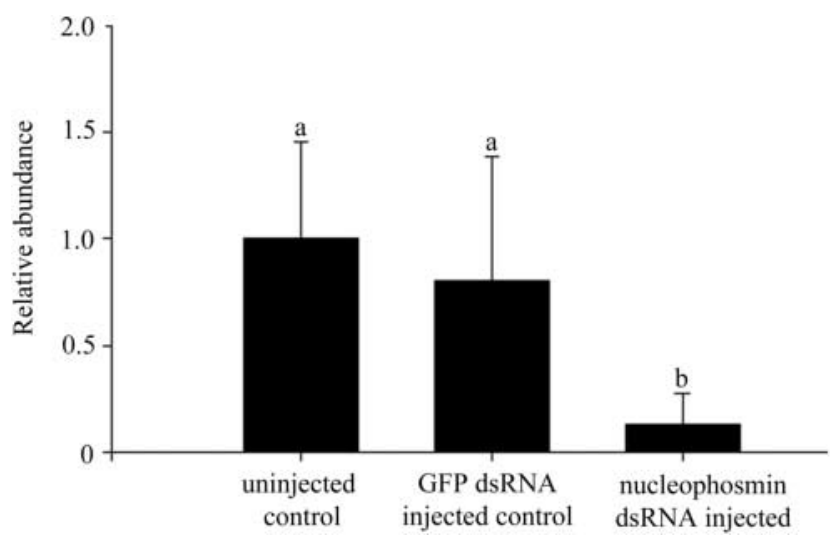

Figure 4 Relative abundance of nucleophosmin mRNA after injection of nucleophosmin dsRNA. The relative abundance ( $y$-axis) represents the amount of nucleophosmin mRNA in a single embryo normalised to the mean of mRNA expression in uninjected embryos in each developmental stage. In total, 15 uninjected, 12 GFP dsRNA-injected and 16 nucleophosmin dsRNA-injected embryos were analysed. Bars shows mean \pm s.D. ${ }^{a, b}$ Values with different superscripts indicate statistical significance $(P<0.05)$. 

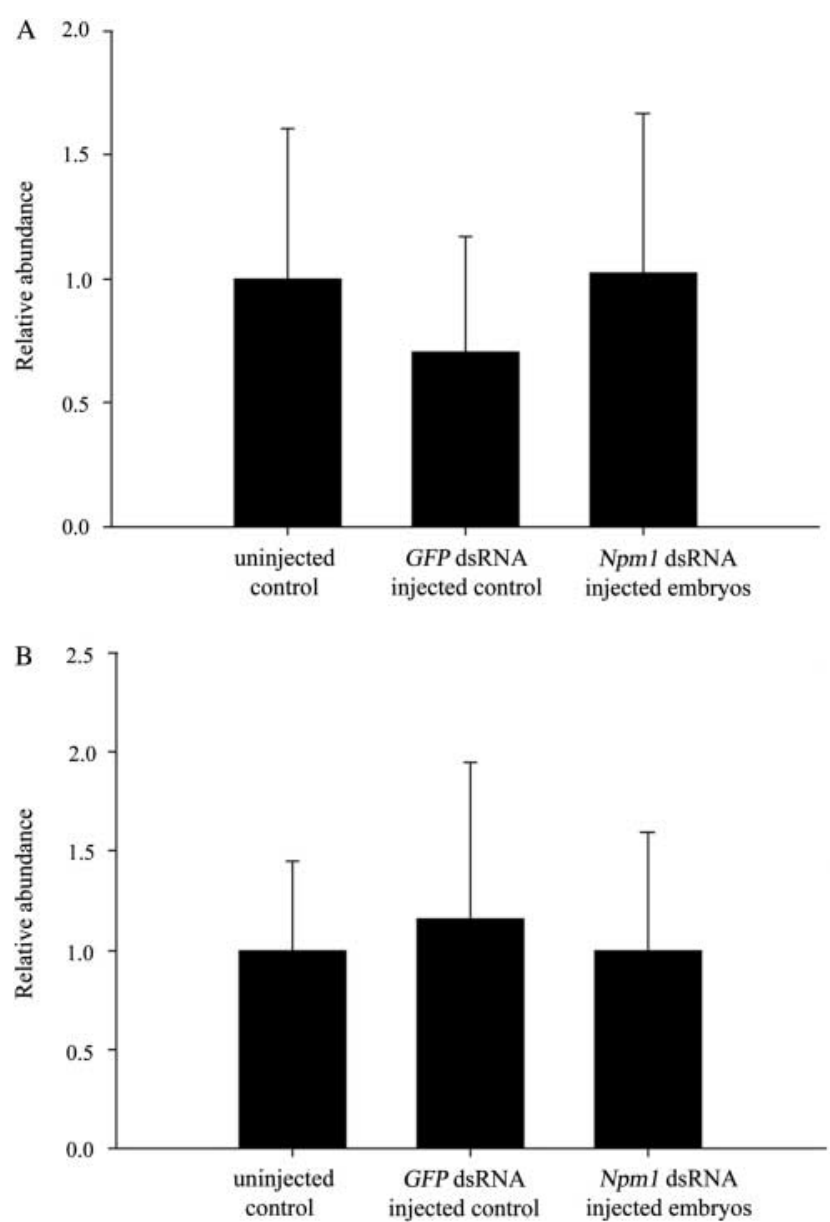

Figure 5 The expression of control genes after injection of nucleophosmin dsRNA. The relative abundance of (A) CENPFand (B) CLEC2D. The relative abundance ( $y$-axis) represents the amount of mRNA in a single embryo normalised to the mean of mRNA expression in uninjected embryos in each developmental stage. Bars show mean \pm s.D.

nucleophosmin staining from the four-cell stage, and only in some embryos. These variances can, however, be caused by different culture media or by the usage of different antibodies (Shinmura et al. 2005).

As the vacuolised nucleoli are being formed at eightcell stage, nucleophosmin generates the so-called shelllike structures (Fig. 2C, $C^{\prime}, C^{\prime \prime}, D, D^{\prime}$, and $D^{\prime \prime}$ ). After EGA, functionally active nucleolus is present from the beginning of the cell cycle and nucleophosmin displays its typical localisation pattern characteristic for somatic cells (Fig. 2E, E', E", F, F', and F"). From day 7 blastocyst, nucleophosmin tended to localise mainly to TE cells and the distinction was apparent especially in hatched blastocysts (Fig. $2 \mathrm{H}^{\prime \prime}$ and $\mathrm{I}^{\prime \prime}$ ). As nucleophosmin is overexpressed in rapidly dividing cells and its downregulation suppresses proliferation (Wang et al. 2006, Okuwaki 2008, Qing et al. 2008, Johansson et al. 2010), the elevated expression in TE cells is likely in connection with preparation for embryo implantation. Correspondingly, Colombo et al. (2005) and Grisendi et al. (2005) showed that the placental structures in $\mathrm{NPM} 1^{-1-}$ mice embryos are smaller, even though normally developed. Interestingly, Johansson \& Simonsson (2010) reported that nucleophosmin forms complexes with ICM markers POU5F1, SOX2 and NANOG in embryonic stem (ES) cells. It is possible that in these protein interactions, one protein silences its binding partner or that nucleophosmin is still needed for ICM development, but low amount is sufficient in this phase.

Svarcova et al. (2007) in bovine embryos and Bjerregaard et al. (2004) in porcine embryos reported that maternal nucleophosmin is stored at least over the EGA stage, but it is not able to localise to the nucleoli. However, both used the general transcription inhibitor $\alpha$-amanitin. Hence, it cannot be distinguished whether maternal nucleophosmin is naturally preserved or whether it is just not degraded due to the absence of another protein. Similarly, it cannot be distinguished whether maternal protein is not able to translocate to the nucleolus or whether this is caused by the absence of some nucleophosmin-translocating protein. Hence, we employed the microinjection of nucleophosmin dsRNA into bovine zygotes, which causes sequence-specific degradation of nucleophosmin mRNA. This experiment showed that relocalisation of the protein is only temporarily delayed at eight-cell stage. However, as soon as at 16-cell stage, it is localised in the same manner as in

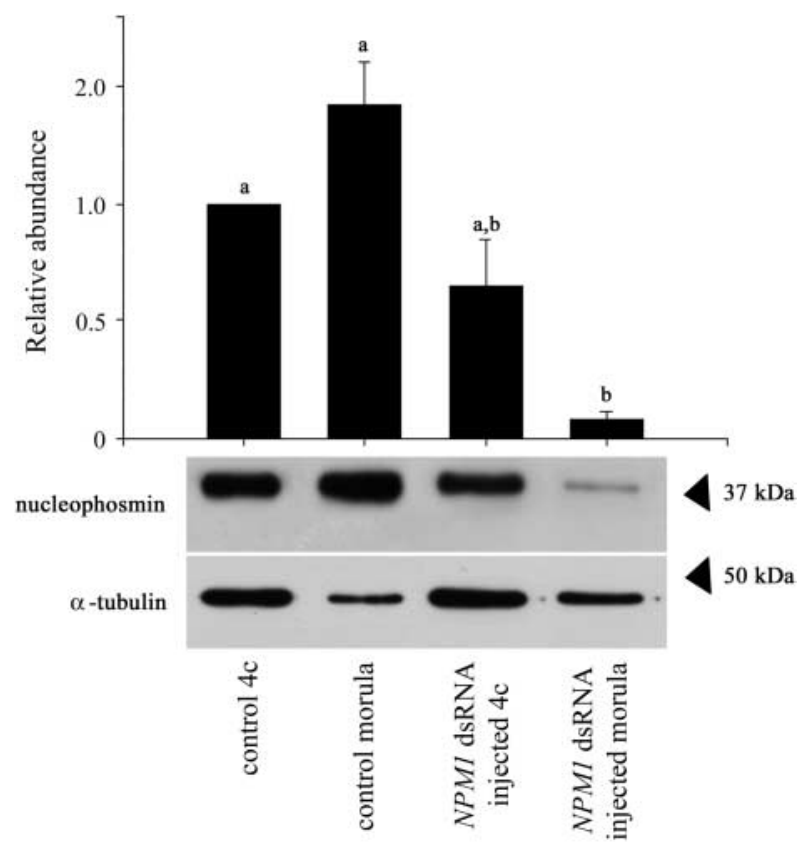

Figure 6 Quantification of nucleophosmin protein level after western blot analysis of bovine embryos at four-cell and morula stages (collection at 44 and $120 \mathrm{hpf}$ respectively) following nucleophosmin dsRNA injection. The expression level of uninjected four-cell stage embryos was considered $100 \%$. Bars show mean \pm s.D. ${ }^{a, b}$ Values with different superscripts indicate statistical significance $(P<0.05)$. The experiment was repeated two times, the representative western blot picture and the loading control using $\alpha$-tubulin antibody are shown below the graph. 


\section{DEVELOPING EMBRYOS}
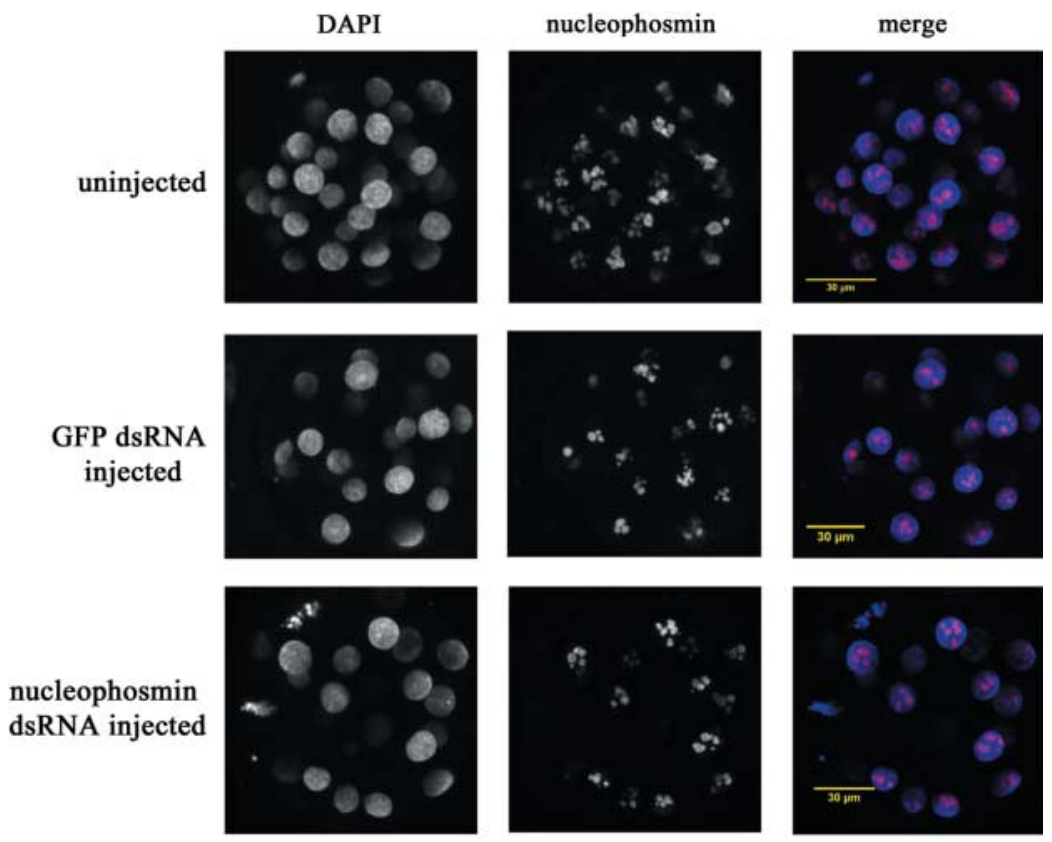

ARRESTED EMBRYOS
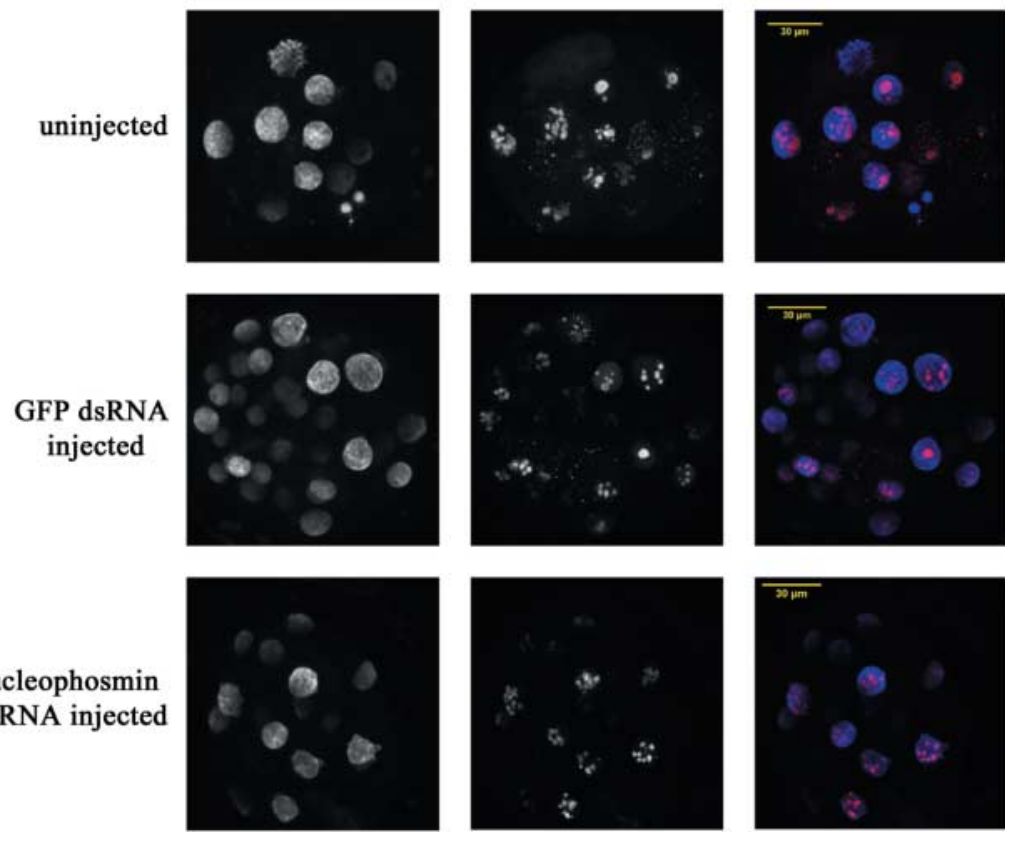

Figure 7 Confocal laser scanning microscopy of normally developing and arrested embryos at morula stage after injection of nucleophosmin dsRNA and corresponding controls. In total, 58 uninjected embryos, 39 GFP dsRNA-injected embryos and 30 nucleophosmin dsRNA-injected embryos were analysed. Nuclei (DAPI) - blue; nucleophosmin - red. control embryos and no localisation differences were found during consequent embryo development (Fig. 7).

Further, we observed no nuclear shape or cytoskeleton defects reported by Amin et al. (2008a) (Fig. 9) and only an undistinguished difference in the developmental competence (Fig. 8). This likely shows that the preserved amount of maternal protein is mostly sufficient. However, as the mRNA expression in single preimplantation embryo is very variable (see s.D. bars in Fig. 4) and the cell number increases, the protein level might become insufficient for some embryos with lower starting amount of the protein, which causes the decrease in developmental competence. In favour of the protein preservation speaks also the result on murine NPM1 ${ }^{-1-}$ mutants (Colombo et al. 2005, Grisendi et al. 2005). The $N P M 1^{-/-}$embryos arrest their development at around midgestation and until then they likely use the pool of nucleophosmin protein synthesised from maternal mRNA.

In conclusion, we show that the transcription of nucleophosmin mRNA from embryonic genome is activated at late eight-cell stage. The protein is present 


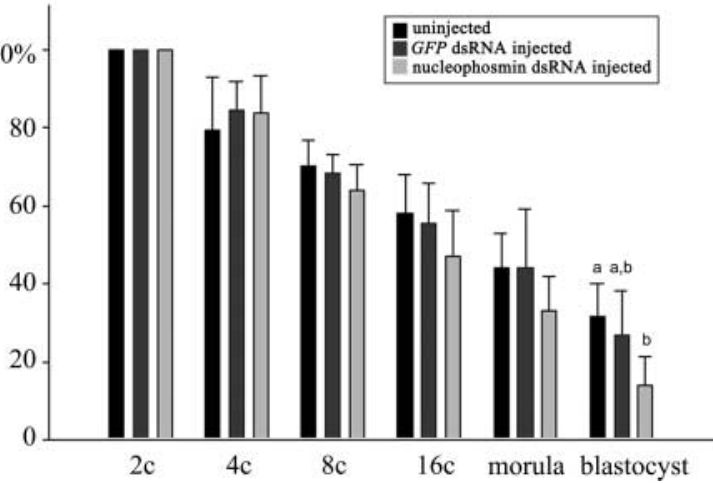

Figure 8 Developmental competence of embryos after injection of nucleophosmin dsRNA. Number of embryos reaching individual developmental stages ( $y$-axis). The number of two-cell stage embryos is considered as $100 \%$. The developmental competence was followed up during four independent experiments; in total, 77 uninjected, 68 GFP dsRNA injected and 65 nucleophosmin dsRNA injected two-cell stage embryos. ${ }^{\mathrm{a}, \mathrm{b}}$ Values with different superscripts indicate $P=0.05$. 2c, two-cell stage embryos; 4c, four-cell stage embryos; $8 \mathrm{c}$, eight-cell stage embryos; 16c, 16-cell stage embryos.

from the beginning of embryonic development and its localisation reflects the formation of the nucleoli. A small amount of maternal protein is preserved throughout the whole preimplantation development and enables almost normal growth of embryos with silenced nucleophosmin mRNA.

\section{Materials and Methods \\ IVF and embryo culture}

Unless otherwise indicated, the chemicals were purchased from Sigma (Sigma-Aldrich) and plastic from Nunclon (Nunc, Roskilde, Denmark). Bovine embryos were obtained after in vitro maturation of oocytes and their subsequent fertilisation and in vitro culture. Briefly, abattoir-derived ovaries from cows and heifers were collected and transported in thermocontainers in sterile saline at about $33^{\circ} \mathrm{C}$. The follicles with diameter between 5 and $10 \mathrm{~mm}$ were dissected with fine scissors and then punctured. The cumulus-oocyte complexes were evaluated and selected according to the morphology of cumulus and submitted to in vitro maturation in TCM 199 (Earle's salt) supplemented with $20 \mathrm{mM}$ sodium pyruvate, $50 \mathrm{U} / \mathrm{ml}$ penicillin, $50 \mu \mathrm{g} / \mathrm{ml}$ streptomycin, $10 \%$ oestrus cow serum (ECS) and gonadotropins (P.G. 600, $15 \mathrm{U} / \mathrm{ml}$; Intervet, Boxmeer, Holland) without paraffin overlay in four-well dishes under humidified atmosphere for $24 \mathrm{~h}$ at $39{ }^{\circ} \mathrm{C}$ with $5 \% \mathrm{CO}_{2}$.

For IVF, the cumulus-oocyte complexes were washed four times in PBS and once in fertilisation medium Tyrode's albumin lactate pyruvate (TALP) and transferred in groups of up to 30 into four-well dishes containing $250 \mu \mathrm{l}$ TALP per well. The TALP medium contained $1.5 \mathrm{mg} / \mathrm{ml} \mathrm{BSA}, 30 \mu \mathrm{g} / \mathrm{ml}$ heparin, $0.25 \mathrm{mM}$ sodium pyruvate, $10 \mathrm{mM}$ lactate and $20 \mu \mathrm{M}$ penicillamine. One straw with frozen sperm of one bull previously tested in the IVF system was thawed in $40^{\circ} \mathrm{C}$ water bath, diluted with $2 \mathrm{ml} \mathrm{TALP}$ and centrifuged at $3500 \mathrm{~g}$ for $10 \mathrm{~min}$. The spermatozoa were layered under $5 \times 1 \mathrm{ml}$ TALP. The supernatant with the motile spermatozoa was isolated after $40 \mathrm{~min}$ of swim-up at $39^{\circ} \mathrm{C}$ (Pavlok et al. 1992). Spermatozoa were counted in a haemocytometer and diluted in the appropriate volume of TALP to give a concentration of $2 \times 10^{6}$ spermatozoa $/ \mathrm{ml}$. A $250 \mu \mathrm{l}$ aliquot of this suspension was added to each fertilisation well to obtain a final concentration of $1 \times 10^{6}$ spermatozoa $/ \mathrm{ml}$. Plates were incubated under humidified atmosphere with $5 \% \mathrm{CO}_{2}$ for $20 \mathrm{~h}$ at $39^{\circ} \mathrm{C}$.

Following fertilisation, presumed zygotes were denuded by gentle pipetting and transferred to EmbryoAssist medium (Origio, Jyllinge, Denmark) supplemented with 10\% ECS and cultured in humidified atmosphere of 5\% $\mathrm{CO}_{2}-5 \% \mathrm{O}_{2}-90 \%$ $\mathrm{N}_{2}$ (25 zygotes in $25 \mu \mathrm{l}$ medium under liquid paraffin; Origio). At morula stage, the EmbryoAssist medium was replaced by BlastAssist medium and embryos were cultivated till hatched blastocyst stage. The dishes were examined at $24 \mathrm{~h}$ postisolation and 32, 44, 56, 92, 104, 120, 156 and $180 \mathrm{~h}$ postfertilisation (hpf), and MII oocytes and two-cell, four-cell, early eight-cell, late eight-cell embryos, 16-cell embryos, morula, blastocysts and hatched blastocysts were collected at each time point respectively.

\section{Quantification of mRNA expression in individual developmental stages}

Poly (A) + mRNA was extracted from the pools of 20 oocytes and embryos in each stage of development, using a Dynabeads mRNA DIRECT Micro Kit (Invitrogen Dynal AS) according to the manufacturer's instructions. Before isolation, 1 pg Luciferase mRNA (Promega) per oocyte/embryo was added as an external standard. Primer sequences were designed using Beacon Designer 7 from bovine nucleophosmin gene
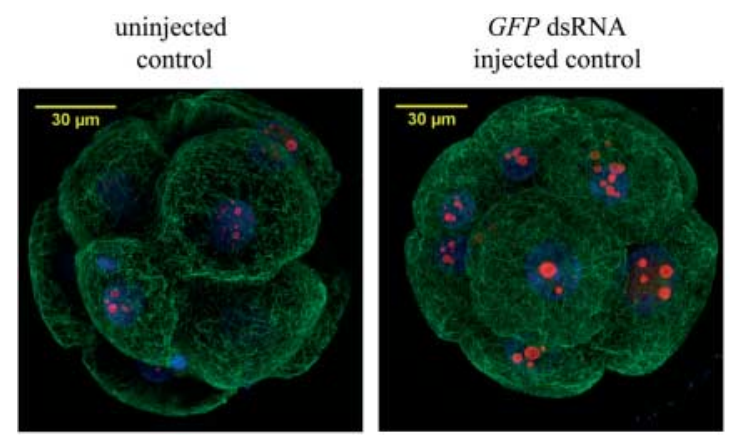

GFP dsRNA nucleophosmin

dsRNA injected

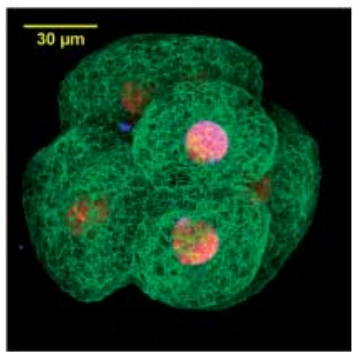

Figure 9 Confocal laser scanning microscopy of eight-cell stage embryos injected with nucleophosmin dsRNA and corresponding controls stained for nucleophosmin and $\alpha$-tubulin as a cytoskeletal protein. In total, 15 uninjected, eight GFP dsRNAinjected and 15 nucleophosmin dsRNA-injected embryos were analysed. Nuclei (DAPI) - blue; nucleophosmin - red; $\alpha$-tubulin - green. 
sequence (GenBank accession number NM_001035441; Table 1). The expression of specific mRNA was measured by quantitative RT-PCR. mRNA equivalent of one embryo was amplified by a OneStep RT-PCR kit (Qiagen) with real-time detection using SybrGreenl fluorescent dye. Reaction composition was QIAGEN OneStep RT-PCR Buffer $(1 \times)$, dNTP Mix (400 $\mu \mathrm{M}$ of each), forward and reverse primers (both $400 \mu \mathrm{M}$ ), SybrGreenl (1:50 000 of $1000 \times$ stock solution; Invitrogen), RNasin Ribonuclease Inhibitor (Promega; $0.2 \mu \mathrm{l}$ ), QIAGEN OneStep RT-PCR Enzyme Mix $(0.5 \mu \mathrm{l})$ and template RNA. Reaction conditions were as follows: RT at $50{ }^{\circ} \mathrm{C}$ for $30 \mathrm{~min}$, initial activation at $95^{\circ} \mathrm{C}$ for $15 \mathrm{~min}$, cycling: denaturation at $94{ }^{\circ} \mathrm{C}$ for $15 \mathrm{~s}$, annealing at $53{ }^{\circ} \mathrm{C}$ for $20 \mathrm{~s}$ and extension at $72{ }^{\circ} \mathrm{C}$ for $30 \mathrm{~s}$. The final extension step was held for $10 \mathrm{~min}$ at $72{ }^{\circ} \mathrm{C}$. The real-time RT-PCRs were run in duplicates, with all samples (oocytes and all embryo stages) in the same reaction. The experiments were carried out on RotorGene 3000 (Corbett Research, Mortlake, NSW, Australia/Qiagen). Fluorescence data were acquired at $3{ }^{\circ} \mathrm{C}$ below the melting temperature to distinguish the possible primer dimers.

The relative concentration of template in different samples was determined using comparative quantification in analysis software (Corbett Research/Qiagen) as described in Kanka et al. (2009). The results were normalised according to the relative concentration of the external standard (Luciferase). The take-off points were calculated as $20 \%$ of the second-derivative maximum level (RotorGene 3000 operation manual; Corbett Research). Products were verified by melting analysis and gel electrophoresis on $1.5 \%$ agarose gel with ethidium bromide staining. Experiment was repeated three times.

\section{$\alpha$-Amanitin treatment}

To block RNA polymerase II-dependent transcription, $\alpha$-amanitin (Sigma-Aldrich) was added to the culture medium at a final concentration of $100 \mu \mathrm{g} / \mathrm{ml}$ either from one-cell stage to four-cell stage (20-44 hpf) or from four-cell stage to late eight-cell stage (44-92 hpf). After the $\alpha$-amanitin treatment, the embryos were washed with PBS, immediately frozen and stored at $-80^{\circ} \mathrm{C}$. Control embryos were collected at the same time interval as their treated counterparts from the same fertilisation/cultivation group, washed with PBS, immediately frozen and stored at $-80{ }^{\circ} \mathrm{C}$. All pools were done in triplicate and contained 20 embryos.

\section{Synthesis of dsRNA}

The RNA for nucleophosmin DNA template synthesis was isolated from bovine fibroblasts using RNeasy Mini Kit (Qiagen). The template was synthesised using primers 'NPM1 dsRNA' (see Table 1). The identity of fibroblastic and embryonic sequence was verified by sequencing. These primers generated amplicons corresponding to the bovine cDNA sequence in GenBank (NM_001035441.1). The green fluorescent protein (GFP) DNA template was amplified from empty p-BluescriptGFP vector (kindly donated by $M$ Anger and $P$ Šolc) using primers 'GFP dsRNA' (Anger et al. 2005; see Table 1). Both pairs of primers were fused with the T7 promoter.

The RT and the PCRs were performed using two-step Phusion RT-PCR kit (Finnzymes, Vantaa, Finland) for nucleophosmin template synthesis; the sole PCR was performed using Phusion Hot Start II DNA Polymerase (Finnzymes) for GFP DNA template synthesis. The RT was performed with oligo(dT) primers and reaction conditions were primer extension at $25^{\circ} \mathrm{C}$ for $10 \mathrm{~min}, \mathrm{cDNA}$ synthesis at $50^{\circ} \mathrm{C}$ for $60 \mathrm{~min}$ and reaction termination at $85^{\circ} \mathrm{C}$ for $5 \mathrm{~min}$. Reaction composition for PCR was $5 \times$ Phusion HF Buffer, dNTP Mix $(600 \mu \mathrm{M}$ of each), forward and reverse primers (both $400 \mu \mathrm{M}$ ), Phusion Hot Start DNA Polymerase $(0.15 \mu \mathrm{l})$ and template RNA. The reaction conditions for $\mathrm{PCR}$ were initial denaturation at $98{ }^{\circ} \mathrm{C}$ for 3 min cycling and denaturation at $98^{\circ} \mathrm{C}$ for $10 \mathrm{~s}$, annealing at $55{ }^{\circ} \mathrm{C}$ for $5 \mathrm{~s}$ and extension at $72{ }^{\circ} \mathrm{C}$ for $30 \mathrm{~s}$. The final extension step was held for $5 \mathrm{~min}$ at $72^{\circ} \mathrm{C}$. The PCR product was purified using QIAquick PCR Purification Kit (Qiagen) and the identity was confirmed by sequencing.

The DNA template coupled with T7 promoter was transcribed in vitro using MEGAscript RNAi Kit (Ambion). An amount of $1 \mu \mathrm{g}$ DNA template was used for each reaction.

Table 1 Primer details.

\begin{tabular}{|c|c|c|c|}
\hline Primer & Sequences & $\begin{array}{c}\text { Annealing } \\
\text { temperature }\left({ }^{\circ} \mathrm{C}\right)\end{array}$ & $\begin{array}{l}\text { Amplicon } \\
\text { size (bp) }\end{array}$ \\
\hline NPM1 (NM_001035441) dsRNA & $\begin{array}{l}\text { 5'-AGGATCCTAATACGACTCACTATAGGGAGAACGATGAC- } \\
\text { GATGATGATGATG-3' } \\
\text { 5'-ACTCGAGTAATACGACTCACTATAGGGAGAACAAG- } \\
\text { CAAAGGGTGGAGTTC-3' }\end{array}$ & 55 & 583 \\
\hline GFP dsRNA ${ }^{\mathrm{a}}$ (Anger et al. 2005) & $\begin{array}{l}\text { 5'-AGGATCCTAATACGACTAACTATAGGGAGAATGGTGAG- } \\
\text { CAAGGGCGAGGA-3' } \\
\text { 5'-ACTCGAGTAATACGACTCACTATAGGGAGAGCGGCCGCTT- } \\
\text { TACTTGTACA-3' }\end{array}$ & 55 & 712 \\
\hline CLEC2D (XM_869843) & $\begin{array}{l}5^{\prime}-\text { CACATGCCACGGAACAGC-3' } \\
5^{\prime}-\text {-CTGCGGAGGACAGATTCTTG-3' }\end{array}$ & 55 & 110 \\
\hline $\begin{array}{l}\text { NPM1 (NM_001035441) } \\
\text { degradation verification }\end{array}$ & $\begin{array}{l}\text { 5'-ACAGCCAACGGTTTCTCTTG-3' } \\
5^{\prime} \text {-ТTTCACСТССТССТССТССТ-3' }\end{array}$ & 55 & 154 \\
\hline CENPF (XM_612376) & $\begin{array}{l}\text { 5'-AGATGAAAGCCAGGCTCACCCAGGAGCTAC-3' } \\
5^{\prime} \text {-TCCAGGTCAGCCAAGGCAAGCTTCAGTTTC-3' }\end{array}$ & 60 & 445 \\
\hline $\begin{array}{l}\text { NPM1 (NM_001035441) mRNA } \\
\text { expression }\end{array}$ & $\begin{array}{l}5^{\prime} \text {-CTGCTGGTTCCAATAGTAGTC-3' } \\
5^{\prime} \text {-CGCCTCTGCTTCAACAAC-3' }\end{array}$ & 53 & 262 \\
\hline Luciferase & $\begin{array}{l}\text { 5'-ACTTCGAAATGTCCGTTCGG-3' } \\
5^{\prime} \text {-ACTTCGAAATGTCCGTTCGG-3' }\end{array}$ & 55 & 633 \\
\hline
\end{tabular}

${ }^{\mathrm{a}}$ Transcribed from empty p-Bluescript-GFP vector; kindly donated by M Anger and P Šolc. 
The reaction mixture was incubated for $5 \mathrm{~h}$ at $37^{\circ} \mathrm{C}$ and the sense and antisense strands were transcribed in the same reaction. The residual DNA template and ssRNA were digested and the dsRNA was purified according to the manufacturer's instruction. One microlitre RNA acquired by in vitro transcription and $1 \mu \mathrm{l}$ final dsRNA were resolved by electrophoresis on $1.5 \%$ agarose gel to confirm the integrity of the dsRNA and efficiency of the annealing step.

\section{Zygote microinjection}

The zygotes were injected $20 \mathrm{hpf}$ at the stage of two pronuclei. dsRNA was dissolved in RNase-free water to a final concentration of $800 \mathrm{ng} / \mu \mathrm{l}$. Two control groups were established the uninjected group and a group injected with GFP dsRNA.

Zygotes were microinjected with $\sim 5 \mathrm{pl}$ of the dsRNA using an MIS-5000 micromanipulator (Burleigh, Exfo Life Sciences, Quebec, QC, Canada) and PM2000B microinjector (MicroData Instrument, South Plainfield, NJ, USA). Pipettes for microinjection were made using P97 Pipette Puller (Sutter Instrument Company, Novato, CA, USA).

In total, 19 independent experiments were performed. Embryos were categorised into the following groups: i) embryos injected with nucleophosmin dsRNA (928 zygotes), ii) embryos injected with GFP dsRNA (665 zygotes) and iii) uninjected embryos (795 zygotes).

After microinjection, embryos were cultivated under standard conditions and collected at early eight-cell, late eight-cell, 16-cell, morula or blastocyst stage (see earlier). The number of embryos that reached each developmental stage was counted and the morphological state of each embryo was determined using phase-contrast technique.

\section{Evaluation of nucleophosmin mRNA degradation}

The embryos fixed after microinjection (GFP and nucleophosmin dsRNA injected) and the uninjected embryos were washed using FCW buffer (a component of FastLane Cell SYBR Green Kit; Qiagen) and stored dry and deep-frozen at $-80{ }^{\circ} \mathrm{C}$ until used. Whole single embryos were lysed in $10 \mu \mathrm{l}$ of the mixture of FCPL buffer and gDNA Wipeout buffer 2 (both components of FastLane Cell RT-PCR kit; Qiagen) according to the manufacturer's instructions and the lysate was directly used for the RT-PCR.

Quantitative RT-PCR was performed using OneStep RT-PCR kit (Qiagen) with real-time detection using SybrGreenl fluorescent dye. In addition to nucleophosmin mRNA evaluation, analysis of CENPF and CLEC2D mRNA expression level was performed as control of degradation specificity. Reaction composition was QIAGEN OneStep RT-PCR buffer $(1 \times)$, dNTP Mix $(400 \mu \mathrm{M}$ each), forward and reverse primers (both $400 \mu \mathrm{M})$, SybrGreenl $(1: 50000$ of $1000 \times$ stock solution; Invitrogen), RNasin Ribonuclease Inhibitor (Promega; $0.2 \mu \mathrm{l}$ ), QIAGEN OneStep RT-PCR Enzyme Mix $(0.5 \mu \mathrm{l})$ and template RNA. For control of degradation efficiency, 'NPM1 degradation verification' primers were used; for control of degradation specificity, CLEC2D and CENPF primers were used (see Table 1). Reaction conditions were RT at $50{ }^{\circ} \mathrm{C}$ for $30 \mathrm{~min}$, initial activation at $95^{\circ} \mathrm{C}$ for $15 \mathrm{~min}$ and cycling: denaturation at $94{ }^{\circ} \mathrm{C}$ for $20 \mathrm{~s}$, annealing at temperature according to the primer for $20 \mathrm{~s}$ and extension at $72{ }^{\circ} \mathrm{C}$ for $30 \mathrm{~s}$. The final extension step was held for $10 \mathrm{~min}$ at $72{ }^{\circ} \mathrm{C}$.

The experiments were carried out on RotorGene 3000 (Corbett Research/Qiagen). Fluorescence data were acquired at $3{ }^{\circ} \mathrm{C}$ below the melting temperature to distinguish the possible primer dimers. The qRT-PCR data were determined using serial dilutions and the standard curve was created using the take-off points. The take-off points were calculated by Internal RotorGene software (Corbett Research) and defined as the cycle at which the second-derivative curve is at $20 \%$ of the maximum rate of fluorescence and indicates the transition to the exponential phase (RotorGene 3000 operation manual; Corbett Research). The starting amount of corresponding RNA in analysed samples was determined by appointing the take-off points to the curve. Products were verified by melting analysis and gel electrophoresis on $1.5 \%$ agarose gel with ethidium bromide staining.

\section{Immunofluorescence}

\section{Nucleophosmin staining}

Embryos were fixed in 4\% paraformaldehyde supplemented with $0.5 \%(\mathrm{v} / \mathrm{v})$ TritonX-100 for $50 \mathrm{~min}$ at $4{ }^{\circ} \mathrm{C}$. Fixed embryos were processed immediately or stored in PBS up to 3 weeks at $4{ }^{\circ} \mathrm{C}$. After washing in PBS, the embryos were incubated in $0.5 \%$ (v/v) TritonX-100 for $15 \mathrm{~min}$. All subsequent steps were done in PBS supplemented with $0.3 \%(\mathrm{w} / \mathrm{v}) \mathrm{BSA}$ and $0.05 \%(\mathrm{w} / \mathrm{v})$ saponin (PBS/BSA/sap). Embryos were blocked with $2 \%(\mathrm{v} / \mathrm{v})$ normal goat serum (NGS; Millipore Biosciences; St Charles, MO, USA) for $1 \mathrm{~h}$ and incubated with mouse anti-nucleophosmin antibody that reacts with C-terminus of the protein (Invitrogen) 1:100 in PBS/BSA/sap overnight at $4{ }^{\circ} \mathrm{C}$. After thorough washing, the embryos were incubated with goat anti-mouse antibody conjugated with Alexa 594 in PBS/BSA/sap for $1 \mathrm{~h}$ at room temperature in the dark. Controls of immunostaining specificity were carried out by omitting primary antibody or using another species-specific secondary antibody conjugate.

\section{Nucleophosmin and $\alpha$-tubulin double staining}

The differences specific for double staining are mentioned below; remaining steps were done as described earlier. Embryos were fixed in $4 \%$ paraformaldehyde for $50 \mathrm{~min}$ at $4{ }^{\circ} \mathrm{C}$ and subsequently permeabilised in $0.5 \%$ TritonX-100 for $10 \mathrm{~min}$ at room temperature. Samples were further incubated with mouse anti-nucleophosmin antibody and consequently with goat antimouse antibody conjugated with Alexa 594. From now on, all steps were performed in dark. After thorough washing, the embryos were incubated in $2 \%(\mathrm{v} / \mathrm{v})$ NGS for $1 \mathrm{~h}$ and then with rabbit anti- $\boldsymbol{\alpha}$-tubulin antibody (Abcam, Cambridge, UK) 1:500 in PBS/BSA/sap overnight at $4{ }^{\circ} \mathrm{C}$. After thorough washing, the embryos were incubated in goat anti-rabbit antibody conjugated with FITC (Santa Cruz Biotechnology, Santa Cruz, CA, USA) for $1 \mathrm{~h}$. Controls of immunostaining specificity were carried out by omitting one or both primary antibodies, while using both secondary antibodies.

The nuclei were stained and the embryos were mounted on glass slides using VECTASHIELD HardSet Mounting Medium 
with DAPI (Vector Laboratories, Peterborough, UK). The samples were examined with Leica TCS SP confocal laser scanning microscope (Leica Microsystems AG, Wetzlar, Germany). The images were processed using the Image software (NIH, Bethesda, MD; http://rsb.info.nih.gov/ij).

\section{Western blotting}

Unless otherwise indicated, chemicals were purchased from Sigma. Embryos and oocytes (45 per extract for uninjected MII, $4 \mathrm{c}$ and morulas or 26 per extract for injected 4c and morulas and corresponding uninjected controls) were lysed in $15 \mu \mathrm{l} 1 \times$ Blue Loading Buffer (7722, Cell Signaling Technology, Danvers, MA, USA) with dithiothreitol, boiled for $5 \mathrm{~min}$ and subjected to $12 \%$ SDS-PAGE. Proteins were transferred from gels to Immobilon $\mathrm{P}$ membrane (Millipore Biosciences, Billerica, MA, USA) using a semidry blotting system (Whatman Biometra $\mathrm{GmbH}$, Hoettingen, Germany) for $28 \mathrm{~min}$ at $5 \mathrm{~mA} / \mathrm{cm}^{2}$. The blocking of the membrane was performed in $5 \%$ non-fat milk in TBS-Tween buffer (TBS-T, $20 \mathrm{mM}$ Tris, $\mathrm{pH}$ 7.4, $137 \mathrm{mM} \mathrm{NaCl}$ and $0.5 \%$ Tween 20) for $1 \mathrm{~h}$ and incubated overnight with mouse anti-nucleophosmin antibody $(1: 1000)$ or anti- $\boldsymbol{\alpha}$-tubulin antibody $(1: 2000)$ in 5\% non-fat milk/TBS-T. After washing in TBS-T, the membranes were incubated with HRP-conjugated donkey anti-mouse IgG antibody (1:7500; Jackson Immuno Research, Suffolk, UK) in 3\% non-fat milk/TBS-T for $1 \mathrm{~h}$ at room temperature. Proteins were visualised by the ECL-PLUS detection system (Amersham Biosciences) according to the manufacturer's instruction. The data were processed using Quantity One software (Bio-Rad).

The specificity of the anti-nucleophosmin antibody was tested using Nucleophosmin Lysate NBL1-13748 (Novus Biologicals, Littleton, CO, USA). Two hundred microlitres of $1 \times$ Blue Loading Buffer were added to $10 \mu \mathrm{l}$ nucleophosmin lysate or empty vector (supplied with nucleophosmin lysate). Ten microlitres of the mixture were subjected to $12 \%$ SDSPAGE followed by classic western blot procedure (Fig. 3A).

\section{Statistical analyses}

The data were analysed using SigmaStat 3.0 software (Jandel Scientific, San Rafael, CA, USA). The Student's t-test or MannWhitney rank sum tests were used. $P \leq 0.05$ was considered as statistically significant.

\section{Declaration of interest}

The authors declare that there is no conflict of interest that could be perceived as prejudicing the impartiality of the research reported.

\section{Funding}

This work was supported by GACR 523/09/1035; T Toralová was supported by GACR 204/09/H084 and V Benešová and T Toralová were supported by GAUK 43-251133.

\section{Acknowledgements}

The authors are indebted to J Tyleckova, R Hrabakova, V Baran, $P$ Karabinova and L Liskova for their helpful comments and expert assistance during the experiments; to M Kopcikova, J Kankova, J Klucinova, J Sestakova and J Supolikova for the excellent technical assistance and to O Sebesta for his help with the confocal microscope.

\section{References}

Adachi Y, Copeland TD, Hatanaka M \& Oroszlan S 1993 Nucleolar targeting signal of Rex protein of human T-cell leukemia virus type I specifically binds to nucleolar shuttle protein B-23. Journal of Biological Chemistry 268 13930-13934.

Amin MA, Matsunaga S, Uchiyama S \& Fukui K 2008a Depletion of nucleophosmin leads to distortion of nucleolar and nuclear structures in HeLa cells. Biochemical Journal 415 345-351. (doi:10.1042/ BJ20081411)

Amin MA, Matsunaga S, Uchiyama S \& Fukui K 2008b Nucleophosmin is required for chromosome congression, proper mitotic spindle formation, and kinetochore-microtubule attachment in HeLa cells. FEBS Letters $\mathbf{5 8 2}$ 3839-3844. (doi:10.1016/j.febslet.2008.10.023)

Anger M, Stein P \& Schultz RM 2005 CDC6 requirement for spindle formation during maturation of mouse oocytes. Biology of Reproduction 72 188-194. (doi:10.1095/biolreprod.104.035451)

Biggiogera M, Bürki K, Kaufmann SH, Shaper JH, Gas N, Amalric F \& Fakan S 1990 Nucleolar distribution of proteins B23 and nucleolin in mouse preimplantation embryos as visualized by immunoelectron microscopy. Development 110 1263-1270.

Bjerregaard B, Wrenzycki C, Strejcek F, Laurincik J, Holm P, Ochs RL, Rosenkranz C, Callesen H, Rath D, Niemann H et al. 2004 Expression of nucleolar-related proteins in porcine preimplantation embryos produced in vivo and in vitro. Biology of Reproduction 70 867-876. (doi:10.1095/ biolreprod.103.021683)

Borer RA, Lehner CF, Eppenberger HM \& Nigg EA 1989 Major nucleolar proteins shuttle between nucleus and cytoplasm. Cell 56 379-390. (doi:10.1016/0092-8674(89)90241-9)

Camous S, Kopecny V \& Fléchon JE 1986 Autoradiographic detection of the earliest stage of $\left[{ }^{3} \mathrm{H}\right]$-uridine incorporation into the cow embryo. Biology of the Cell 58 195-200. (doi:10.1111/j.1768-322X.1986.tb00506.x)

Chen D \& Huang S 2001 Nucleolar components involved in ribosome biogenesis cycle between the nucleolus and nucleoplasm in interphase cells. Journal of Cell Biology 153 169-176. (doi:10.1083/jcb.153.1.169)

Colombo E, Bonetti P, Lazzerini Denchi E, Martinelli P, Zamponi R, Marine J-C, Helin K, Falini B \& Pelicci PG 2005 Nucleophosmin is required for DNA integrity and p19Arf protein stability. Molecular and Cellular Biology 25 8874-8886. (doi:10.1128/MCB.25.20.8874-8886. 2005)

Fair T, Hyttel P, Lonergan P \& Boland MP 2001 Immunolocalisation of nucleolar proteins during bovine oocyte growth, meiotic maturation, and fertilization. Biology of Reproduction 64 1516-1525. (doi:10.1095/ biolreprod64.5.1516)

Fankhauser C, Izaurralde E, Adachi Y, Wingfield P \& Laemmli UK 1991 Specific complex of human immunodeficiency virus type $1 \mathrm{rev}$ and nucleolar B23 proteins: dissociation by the Rev response element. Molecular and Cellular Biology 11 2567-2575.

Grisendi S, Bernardi R, Rossi M, Cheng K, Khandker L, Manova K \& Pandolfi PP 2005 Role of nucleophosmin in embryonic development and tumorigenesis. Nature 437 147-153. (doi:10.1038/nature03915)

Hamatani T, Carter MG, Sharov AA \& Ko MSH 2004 Dynamics of global gene expression changes during mouse preimplantation development. Developmental Cell 6 117-131. (doi:10.1016/S1534-5807(03)00373-3)

Hingorani K, Szebeni A \& Olson MO 2000 Mapping the functional domains of nucleolar protein B23. Journal of Biological Chemistry 275 24451-24457. (doi:10.1074/jbc.M003278200)

Johansson H \& Simonsson S 2010 Core transcription factors, Oct4, Sox2 and Nanog, individually form complexes with nucleophosmin (Npm1) to control embryonic stem (ES) cell fate determination. Aging 2 815-822. 
Johansson H, Vizlin-Hodzic D, Simonsson T \& Simonsson S 2010 Translationally controlled tumor protein interacts with nucleophosmin during mitosis in ES cells. Cell Cycle 9 2160-2169. (doi:10.4161/cc.9. 11.11841)

Kanka J 2003 Gene expression and chromatin structure in the preimplantation embryo. Theriogenology 59 3-19. (doi:10.1016/S0093691X(02)01267-0)

Kanka J, Kepkova K \& Nemcova L 2009 Gene expression during minor genome activation in preimplantation bovine development. Theriogenology 72 572-583. (doi:10.1016/j.theriogenology.2009.04.014)

King WA, Niar A, Chartrain I, Betteridge KJ \& Guay P 1988 Nucleolus organizer regions and nucleoli in preattachment bovine embryos. Journal of Reproduction and Fertility 82 87-95. (doi:10.1530/jrf.0. 0820087)

Kopecny V, Fléchon JE, Camous S \& Fulka J Jr 1989 Nucleologenesis and the onset of transcription in the eight-cell bovine embryo: fine-structural autoradiographic study. Molecular Reproduction and Development 1 79-90. (doi:10.1002/mrd.1080010202)

Laurincik J, Thomsen PD, Hay-Schmidt A, Avery B, Greve T, Ochs RL \& Hyttel P 2000 Nucleolar proteins and nuclear ultrastructure in preimplantation bovine embryos produced in vitro. Biology of Reproduction 62 1024-1032. (doi:10.1095/biolreprod62.4.1024)

Li YP, Busch RK, Valdez BC \& Busch H 1996 C23 interacts with B23, a putative nucleolar-localisation-signal-binding protein. European Journal of Biochemistry 237 153-158. (doi:10.1111/j.1432-1033.1996. 0153n.x)

Memili E \& First NL 1998 Developmental changes in RNA polymerase II in bovine oocytes, early embryos, and effect of $\alpha$-amanitin on embryo development. Molecular Reproduction and Development 51 381-389. (doi:10.1002/(SICI)1098-2795(199812)51:4<381::AID-MRD4>3.0. $\mathrm{CO} ; 2-\mathrm{G})$

Nganvongpanit K, Müller H, Rings F, Gilles M, Jennen D, Hölker M, Tholen E, Schellander K \& Tesfaye D 2006a Targeted suppression of E-cadherin gene expression in bovine preimplantation embryo by RNA interference technology using double-stranded RNA. Molecular Reproduction and Development 73 153-163. (doi:10.1002/mrd.20406)

Nganvongpanit K, Müller H, Rings F, Hoelker M, Jennen D, Tholen E, Havlicek V, Besenfelder U, Schellander K \& Tesfaye D $2006 b$ Selective degradation of maternal and embryonic transcripts in in vitro produced bovine oocytes and embryos using sequence specific double-stranded RNA. Reproduction 131 861-874. (doi:10.1530/rep.1.01040)

Okuwaki M 2008 The structure and functions of NPM1/Nucleophsmin/B23, a multifunctional nucleolar acidic protein. Journal of Biochemistry 143 441-448. (doi:10.1093/jb/mvm222)

Okuwaki M, Tsujimoto M \& Nagata K 2002 The RNA binding activity of a ribosome biogenesis factor, nucleophosmin/B23, is modulated by phosphorylation with a cell cycle-dependent kinase and by association with its subtype. Molecular Biology of the Cell 13 2016-2030. (doi:10.1091/mbc.02-03-0036)

Pavlok A, Lucas-Hahn A \& Niemann H 1992 Fertilization and developmental competence of bovine oocytes derived from different categories of antral follicles. Molecular Reproduction and Development 31 63-67. (doi:10.1002/mrd.1080310111)

Pavlok A, Kopecny V, Lucas-Hahn A \& Niemann H 1993 Transcriptional activity and nuclear ultrastructure of 8-cell bovine embryos developed by in vitro maturation and fertilization of oocytes from different growth categories of antral follicles. Molecular Reproduction and Development 35 233-243. (doi:10.1002/mrd.1080350304)
Qing Y, Yingmao G, Lujun B \& Shaoling L 2008 Role of Npm1 in proliferation, apoptosis and differentiation of neural stem cells. Journal of the Neurological Sciences 266 131-137. (doi:10.1016/j.jns.2007. 09.029)

Salilew-Wondim D, Hölker M, Rings F, Phatsara C, MohammadiSangcheshmeh A, Tholen E, Schellander K \& Tesfaye D 2010 Depletion of BIRC6 leads to retarded bovine early embryonic development and blastocyst formation in vitro. Reproduction, Fertility, and Development 22 564-579. (doi:10.1071/RD09112)

Savkur RS \& Olson MO 1998 Preferential cleavage in pre-ribosomal RNA by protein B23 endoribonuclease. Nucleic Acids Research 26 4508-4515. (doi:10.1093/nar/26.19.4508)

Shinmura K, Tarapore P, Tokuyama Y, George KR \& Fukasawa K 2005 Characterization of centrosomal association of nucleophosmin/B23 linked to Crm1 activity. FEBS Letters 579 6621-6634. (doi:10.1016/j. febslet.2005.10.057)

Spector DL, Ochs RL \& Busch H 1984 Silver staining, immunofluorescence, and immunoelectron microscopic localisation of nucleolar phosphoproteins B23 and C23. Chromosoma 90 139-148. (doi:10.1007/ BF00292451)

Svarcova O, Laurincik J, Avery B, Mlyncek M, Niemann H \& MaddoxHyttel P 2007 Nucleolar development and allocation of key nucleolar proteins require de novo transcription in bovine embryos. Molecular Reproduction and Development 74 1428-1435. (doi:10.1002/mrd. 20727)

Swaminathan V, Kishore AH, Febitha KK \& Kundu TK 2005 Human histone chaperone nucleophosmin enhances acetylation-dependent chromatin transcription. Molecular and Cellular Biology 25 7534-7545. (doi:10.1128/MCB.25.17.7534-7545.2005)

Toralova T, Susor A, Nemcova L, Kepkova K \& Kanka J 2009 Silencing CENPF in bovine preimplantation embryo induces arrest at 8-cell stage. Reproduction 138 783-791. (doi:10.1530/REP-09-0234)

Valdez BC, Perlaky L, Henning D, Saijo Y, Chan PK \& Busch H 1994 Identification of the nuclear and nucleolar localisation signals of the protein p120. Interaction with translocation protein B23. Journal of Biological Chemistry $26923776-23783$.

Vodickova Kepkova K, Vodicka P, Toralova T, Lopatarova M, Cech S, Dolezel R, Havlicek V, Besenfelder U, Kuzmany A, Sirard MA et al. 2011 Transcriptomic analysis of in vivo and in vitro produced bovine embryos revealed a developmental change in cullin 1 expression during maternalto-embryonic transition. Theriogenology 75 1582-1595. (doi:10.1016/j. theriogenology.2010.12.019)

Wang BB, Lu R, Wang WC \& Jin Y 2006 Inducible and reversible suppression of Npm1 gene expression using stably integrated small interfering RNA vector in mouse embryonic stem cells. Biochemical and Biophysical Research Communications 347 1129-1137. (doi:10.1016/j. bbrc.2006.07.020)

Yung BY, Bor AM \& Yang YH 1990 Immunolocalisation of phosphoprotein B23 in proliferating and non-proliferating HeLa cells. International Journal of Cancer 46 272-275. (doi:10.1002/ijc.2910460222)

Received 25 January 2012

First decision 2 March 2012

Revised manuscript received 8 June 2012

Accepted 22 June 2012 